\title{
ANALISIS KEPUASAN PASIEN TERHADAP STANDAR PELAYANAN KEFARMASIAN DI PUSKESMAS SEMPAJA SAMARINDA
}

\author{
Mi'atu Khabbah*, Rolan Rusli, Welinda Dyah Ayu, Nurul Annisa \\ Laboratorium penelitian dan pengembangan FARMAKA TROPIS \\ Fakultas Farmasi Universitas Mulawarman, Samarinda, Kalimantan Timur \\ *Email : khabbahmiatu@gmail.com
}

\begin{abstract}
ABSTRAK
Kepuasan pasien terhadap standar pelayanan kefarmasian di puskesmas dapat diukur dengan membandingkan antara harapan pasien terhadap kualitas pelayanan kefarmasian yang diinginkan dengan kenyataan yang diterimanya. Penelitian ini bertujuan untuk mengetahui kepuasan pasien dan pelaksanaan standar minimal pelayanan kefarmasian di Puskesmas. Penelitian observasi deskriptif dilakukan terhadap 270 responden menggunakan metode incidental sampling. Data dikumpulkan melalui kuisioner kepuasan pasien dan standar pelayanan minimal di Puskesmas. Hasil penelitian menunjukkan bahwa $81,75 \%$ responden puas terhadap pelayanan yang diberikan puskesmas. Standar pelayanan waktu tunggu resep di bagian farmasi Puskesmas dapat dikatakan baik dan hampir memenuhi standar pelayanan kefarmasian di Puskesmas.
\end{abstract}

Kata Kunci : Standar Pelayanan Kefarmasian, Kepuasan pasien, Puskesmas, incidental sampling

\begin{abstract}
Patient's satisfactory towards pharmaceutical care at Primary Health Facility measured by comparing between patient's expectations of pharmaceutical care quality with the real service that the patient has received. This research purpose is to find out patient's satisfaction and minimum standard pharmaceutical service implemented at Primary Health Facility. This research carried out with a descriptive observation method using an incidental sampling method with a total of 270 respondents. The data collected by using a questionnaire about minimal service standards at a Primary Health. The result shows that respondent's satisfactory from the type of service given by Primary Health Facility stated as "satisfactory" with the average percentage of $81,75 \%$ and as for prescription's waiting time service standard stated as "good" and almost fulfill the pharmaceutical service standard at a Primary Health Facility.
\end{abstract}

Keywords : Standard of Pharmaceutical Care, Respondents Satisfactory, Primary Health Facility, Incidental Sampling 


\section{PENDAHULUAN}

Standar pelayanan kefarmasian di puskesmas secara khusus dibuat dalam Peraturan Menteri Kesehatan Republik Indonesia Nomor 74 Tahun 2016, farmasis harus memberikan pelayanan obat dan pelayanan klinik. Pelayanan obat mencakup perencanaan kebutuhan obat dan bahan medis habis pakai, permintaan obat dan bahan habis pakai, penerimaan obat dan bahan habis pakai, penyimpanan obat dan bahan habis pakai, pendistribusian obat dan bahan habis pakai, pengendalian obat dan bahan habis pakai, pencatatan, pelaporan dan pengarsipan serta pemantauan dan evaluasi obat dan bahan habis pakai. Sedangkan pelayanan klinik mencakup pengkajian resep, pelayanan informasi obat (PIO), konseling, ronde/ visite pasien, pemantauan terapi obat (PTO), dan monitoring efek samping obat (Menkes RI, 2016).

Berdasarkan permenkes tersebut, perlu dilakukan kajian mengenai kepuasan pasien terhadap standar pelayanan kefarmasian yang dilakukan di Puskesmas Sempaja Samarinda. Hal ini dimaksudkan untuk mengetahui tingkat kepuasan pasien terhadap pelayanan kefarmasian, serta untuk mengetahui kesesuaian pelayanan kefarmasian yang diterapkan terhadap standar pelayanan kefarmasian berdasarkan permenkes tersebut.

\section{METODE PENELITIAN}

Penelitian ini dilakukan dengan menggunakan metode observasional kepada pasien Puskesmas Sempaja Samarinda periode Februari - Maret 2017. Penelitian ini merupakan jenis penelitian kualitatif dengan rancangan secara deskriptif. Pengumpulan data dilakukan secara prospektif. Jumlah responden dalam penelitian ini sebanyak 270 responden. Teknik pengambilan sampel pada penelitian ini dilakukan dengan teknik incidental sampling. (Sugiyono, 2010).

\section{HASIL DAN PEMBAHASAN}

Tingkat kepuasan responden diukur menggunakan kuisioner kepuasan pasien berdasarkan Peraturan Menteri Kesehatan Republik Indonesia Nomor 74 Tahun 2016 yang terdiri dari lima dimensi kualitas pelayanan yakni 
responsiveness, emphaty, reliability, assurance, dan tangible. Pelaksanaan standar pelayanan kefarmasian di Puskesmas berdasarkan permenkes tersebut disajikan pada tabel 1.

Tabel 1. Kepuasan pasien terhadap standar pelayanan kefarmasian

\begin{tabular}{|c|c|c|c|c|}
\hline \multirow[b]{2}{*}{ No } & \multirow[b]{2}{*}{ Jenis Pelayanan } & \multicolumn{3}{|c|}{ Jawaban Responden } \\
\hline & & $\begin{array}{c}\text { Sangat Puas } \\
(\%)\end{array}$ & $\begin{array}{l}\text { Puas } \\
(\%)\end{array}$ & $\begin{array}{c}\text { Tidak Puas } \\
(\%)\end{array}$ \\
\hline 1. & $\begin{array}{l}\text { Ketanggapan Apoteker } \\
\text { terhadap Pasien }\end{array}$ & 8,5 & 87,4 & 4,1 \\
\hline 2. & Keramahan Apoteker & 9,6 & 90 & 0,4 \\
\hline 3. & $\begin{array}{l}\text { Kejelasan Apoteker dalam } \\
\text { Memberikan Informasi } \\
\text { Obat }\end{array}$ & 14,8 & 82,6 & 2,6 \\
\hline 4. & Kecepatan Pelayanan Obat & 9,6 & 78,5 & 11,9 \\
\hline 5. & $\begin{array}{l}\text { Kelengkapan Obat dan } \\
\text { Alat Kesehatan }\end{array}$ & 6,7 & 78,9 & 14,4 \\
\hline 6. & $\begin{array}{l}\text { Kenyamanan Ruang } \\
\text { Tunggu }\end{array}$ & 10,7 & 77 & 12,3 \\
\hline 7. & Kebersihan Ruang Tunggu & 11,9 & 80 & 8,1 \\
\hline 8. & $\begin{array}{l}\text { Ketersediaan Brosur, } \\
\text { Leaflet, Poster dan Lain- } \\
\text { lain Sebagai Informasi } \\
\text { Obat/ Kesehatan }\end{array}$ & 5,6 & 79,6 & 14,8 \\
\hline & Total & 9,67 & 81,75 & 8,58 \\
\hline
\end{tabular}


Tabel 2. Pelaksanaan standar pelayanan kefarmasian di Puskesmas Sempaja Samarinda

\begin{tabular}{|c|c|c|c|}
\hline \multirow{2}{*}{ No } & \multirow{2}{*}{ Daftar Pelayanan } & \multicolumn{2}{|c|}{ Hasil Pengamatan } \\
\hline & & Ya $(\%)$ & Tidak (\%) \\
\hline 1. & $\begin{array}{l}\text { Skrining resep : } \\
\text { Menanyakan nama pasien } \\
\text { Menanyakan asal dokter }\end{array}$ & $\begin{array}{l}100 \\
98,9\end{array}$ & $\begin{array}{l}0 \\
1,1\end{array}$ \\
\hline 2. & Pelayanan resep obat jadi $<30$ menit & 97 & 3 \\
\hline 3. & $\begin{array}{l}\text { Pelayanan resep racikan jadi }<60 \\
\text { menit }\end{array}$ & 8,1 & 0 \\
\hline 4. & $\begin{array}{l}\text { Informasi penggunaan obat oleh } \\
\text { Apoteker: } \\
\text { Informasi mengenai dosis obat } \\
\text { Informasi mengenai cara penggunaan } \\
\text { obat } \\
\text { Informasi mengenai efek samping obat } \\
\text { Informasi mengenai keamanan dalam } \\
\text { penggunaan obat } \\
\text { Informasi mengenai interaksi obat } \\
\text { yang harus dihindarkan }\end{array}$ & $\begin{array}{l}100 \\
99,6 \\
55,6 \\
97,8 \\
48,9\end{array}$ & $\begin{array}{l}0 \\
0,4 \\
44,4 \\
2.2 \\
51,1\end{array}$ \\
\hline 5. & Konseling obat yang digunakan & 73 & 27 \\
\hline 6. & $\begin{array}{l}\text { Menanyakan kejelasan informasi yang } \\
\text { diberikan }\end{array}$ & 63 & 37 \\
\hline 7. & Apoteker ramah dan murah senyum & 99,6 & 0,4 \\
\hline 8. & $\begin{array}{l}\text { Apoteker memberikan perhatian dan } \\
\text { motivasi agar cepat sembuh }\end{array}$ & 0 & 100 \\
\hline & & 72,4 & 20,5 \\
\hline
\end{tabular}

\section{Kepuasan responden berdasarkan dimensi responsiveness (Ketanggapan)}

Hasil penelitian dapat diketahui bahwa kepuasan responden Puskesmas Sempaja Samarinda periode Februari-Maret 2017 berdasarkan dimensi responsiveness. Dimensi ini bertujuan untuk melihat kemampuan Apoteker dalam melayani pasien dengan cepat dan tepat. Kepuasan responden terhadap ketanggapan Apoteker disajikan dalam tabel 3. 
Tabel 3. Kepuasan pasien terhadap standar pelayanan kefarmasian berdasarkan dimensi responsiveness.

\begin{tabular}{|l|l|c|c|c|}
\hline \multirow{2}{*}{ No } & \multicolumn{2}{|c|}{ Jenis Pelayanan } & \multicolumn{3}{|c|}{ Jawaban Responden } \\
\cline { 3 - 5 } & \multicolumn{2}{|c|}{$\begin{array}{c}\text { Sangat Puas } \\
(\mathbf{\%})\end{array}$} & $\begin{array}{c}\text { Puas } \\
(\mathbf{\%})\end{array}$ & $\begin{array}{c}\text { Tidak Puas } \\
(\boldsymbol{\%})\end{array}$ \\
\hline 1. & $\begin{array}{l}\text { Ketanggapan Apoteker } \\
\text { terhadap Pasien }\end{array}$ & 8,5 & 87,4 & 4,1 \\
\hline
\end{tabular}

Berdasarkan hasil penelitian yang diamati oleh peneliti diketahui bahwa pelaksanaan skrining resep di Puskesmas Sempaja Samarinda dilakukan dengan menanyakan nama pasien atau identitas pasien 100\%. Sedangkan untuk menanyakan darimana poli pengobatan yang sebelumnya pasien lakukan hanya 98,9\%. Sehingga kepuasan responden terhadap ketanggapan Apoteker dapat dikatakan puas karena sesuai dengan hasil pengamatan yang dilakukan peneliti terhadap ketanggapan Apoteker.

Kepuasan responden terhadap kecepatan pelayanan obat yaitu sangat puas dengan persentase $9,6 \%$, puas sebesar $78,5 \%$, dan tidak puas sebesar $11,9 \%$, sehingga dapat dikatakan puas.

Berdasarkan hasil penelitian yang diamati oleh peneliti diketahui bahwa waktu pelayanan resep obat jadi kurang dari 30 menit sebesar $97 \%$ dan yang lebih dari 30 menit sebesar 3\%. Sedangkan waktu pelayanan resep racikan kurang dari 60 menit sebesar 8,1\% dan yang lebih dari 60 menit tidak ada. Hal tersebut hampir memenuhi standar pelayanan minimal yang dipersyaratkan oleh Kepmenkes No 129/Menkes/SK/II/2008 tentang pelayanan resep baik obat jadi maupun obat racikan yaitu lama waktu tunggu obat jadi kurang dari 30 menit dan obat racikan kurang dari 60 menit.

\section{Kepuasan responden berdasarkan dimensi emphaty (Empati dan perhatian)}

Kepuasan responden Puskesmas Sempaja Samarinda periode Februari Maret 2017 berdasarkan dimensi emphaty menunjukkan bahwa kepuasan responden terhadap keramahan Apoteker dapat dikatakan puas. Dimensi empati bertujuan untuk melihat kemampuan Apoteker dalam memahami kebutuhan pasien. Kepuasan responden terhadap dimensi empati di sajikan dalam tabel 4. 
Tabel 4. Kepuasan pasien terhadap standar pelayanan kefarmasian berdasarkan dimensi emphaty.

\begin{tabular}{|c|c|c|c|c|}
\hline \multirow{2}{*}{ No } & \multirow{2}{*}{ Jenis Pelayanan } & \multicolumn{3}{|c|}{ Jawaban Responden } \\
\cline { 3 - 5 } & & $\begin{array}{c}\text { Sangat Puas } \\
(\boldsymbol{\%})\end{array}$ & $\begin{array}{c}\text { Puas } \\
(\boldsymbol{\%})\end{array}$ & $\begin{array}{c}\text { Tidak Puas } \\
(\boldsymbol{\%})\end{array}$ \\
\hline 1. & Keramahan Apoteker & 9 & 90 & 1 \\
\hline
\end{tabular}

Berdasarkan hasil penelitian yang diamati oleh peneliti diketahui bahwa 99,6\% Apoteker telah bersikap ramah dan murah senyum kepada pasien. Apoteker di Puskesmas Sempaja tidak memiliki sikap perhatian kepada pasien dengan persentase $0 \%$.

\section{Kepuasan responden berdasarkan dimensi reliability (Kehandalan)}

Hasil penelitian dapat diketahui bahwa kepuasan responden Puskesmas Sempaja Samarinda periode Februari - Maret 2017 berdasarkan dimensi reliability. Dimensi ini bertujuan untuk melihat kemampuan Apoteker dalam memberikan pelayanan yang memuaskan pasien. Kepuasan responden terhadap dimensi reliability disajikan dalam tabel 5 .

Tabel 5. Kepuasan pasien terhadap standar pelayanan kefarmasian berdasarkan dimensi reliability.

\begin{tabular}{|l|l|c|c|c|}
\hline \multirow{2}{*}{ No } & \multicolumn{1}{|c|}{ Jenis Pelayanan } & \multicolumn{3}{|c|}{ Jawaban Responden } \\
\cline { 3 - 5 } & $\begin{array}{c}\text { Sangat Puas } \\
(\mathbf{\%})\end{array}$ & $\begin{array}{c}\text { Puas } \\
(\boldsymbol{\%})\end{array}$ & $\begin{array}{c}\text { Tidak Puas } \\
(\boldsymbol{\%})\end{array}$ \\
\hline 1. & $\begin{array}{l}\text { Kejelasan Apoteker dalam } \\
\text { Memberikan Informasi } \\
\text { Obat }\end{array}$ & 14,8 & 82,6 & 2,6 \\
\hline
\end{tabular}

Berdasarkan hasil penelitian yang diamati oleh peneliti diketahui bahwa penyampaian informasi mengenai dosis obat di Puskesmas Sempaja Samarinda $100 \%$ dilakukan. bahwa penyampaian informasi mengenai cara penggunaan obat 99,6\% telah dilakukan. Penyampaian informasi mengenai efek samping obat 55,6\% telah dilakukan. Penyampaian informasi mengenai keamanan dalam penggunaan obat $97,8 \%$ telah dilakukan. Penyampaian informasi mengenai interaksi dalam 
penggunaan obat hanya 48,9\% yang telah dilakukan. penyampaian konseling obat $73 \%$ telah dilakukan. pelaksanaan verifikasi $63 \%$ telah dilakukan.

Kepuasan responden berdasarkan dimensi reliability dapat dikatakan puas karena hasil pengamatan yang dilakukan peneliti di Apotek Puskesmas Sempaja terhadap penyampaian informasi obat dilakukan dengan baik kecuali penyampaian efek samping obat dan interaksi dalam penggunaan obat masih kurang optimal. Dari hasil pengamatan yang dilakukan oleh peneliti Puskesmas Sempaja Samarinda telah melakukan konseling penggunaan obat dan melaksanakan verifikasi informasi penggunaan obat

\section{Kepuasan responden berdasarkan dimensi assurance (Jaminan)}

Hasil penelitian menunjukkan bahwa kepuasan responden terhadap kelengkapan obat dan alat kesehatan yaitu sangat puas dengan persentase $6,7 \%$, puas sebesar $78,9 \%$, dan tidak puas sebesar $14,8 \%$, sehingga dapat dikatakan responden puas dengan kelengkapan obat dan alat kesehatan di Puskesmas Sempaja Samarinda yang merupakan murni jawaban dari responden. Dimensi assurance bertujuan untuk melihat kemampuan Apoteker dalam memberikan kepercayaan dan kebenaran atas pelayanan yang diberikan kepada pasien. Kelengkapan obat dan alat kesehatan merupakan faktor yang sangat penting dalam pelayanan kesehatan karena dalam menjalankan aktivitas pelayanan kesehatan salah satu sumber daya yang sangat penting adalah persediaan obat-obatan. Seperti yang dikatakan Pudjaningsih (2007) persediaan obat-obatan harus disesuaikan dengan besarnya kebutuhan pengobatan. Karena persediaan obat-obatan yang tidak lancar akan menghambat pelayanan kesehatan, hal ini disebabkan karena obat tidak tersedia pada saat dibutuhkan, sehingga pelayanan kefarmasian tidak berjalan dengan baik dan mengganggu proses pengobatan.

\section{Kepuasan responden berdasarkan dimensi tangible (Berwujud)}

Hasil penelitian menunjukkan bahwa nilai kepuasan responden terhadap kenyamanan ruang tunggu dan kebersihan ruang tunggu dapat dikatakan puas dengan persentase $77 \%$ dan $80 \%$. Kenyamanan dan kebersihan ruang tunggu merupakan salah satu faktor kepuasan responden dan merupakan dimensi yang 
sangat penting karena lingkungan ruang tunggu yang nyaman dan bersih dapat membantu proses penyembuhan pasien.

Hasil penelitian menunjukkan bahwa kepuasan responden terhadap tersedianya brosur, poster, leaflet sebagai informasi obat/kesehatan dapat dikatakan puas dengan persentase $79,6 \%$. Dengan tersedianya brosur, poster, leaflet dan lainlain akan sangat membantu pasien dalam memahami penyakit yang diderita serta informasi pengobatan yang tidak tersampaikan oleh petugas kesehatan, sehingga dapat membantu menambah pengetahuan pasien terhadap obat yang diterima untuk penyakit yang dideritanya. Dalam pengamatan langsung tersedian brosur dan poster mengenai cara cuci tangan yang benar, cara mencegah penyakit demam berdarah, DAGUSIBU, dan perkembangan anak dari usia 1 bulan sampe 5 tahun.

\section{KESIMPULAN}

Hasil penelitian menunjukkan bahwa $81,75 \%$ responden puas terhadap pelayanan kefarmasian yang diberikan Puskesmas. Belum optimalnya aspek pelaksanaan standar pelayanan kefarmasian di Puskesmas seperti informasi keamanan dalam penggunaan obat, interaksi obat, konseling, verifikasi, dan perhatian Apoteker, masih belum dilaksanakan dengan optimal.

\section{DAFTAR PUSTAKA}

Depkes RI,2002. Keputusan Menteri Kesehatan no.1332/kep/v/2002 tentang Perubahan atas Peraturan Menteri Kesehatan no. 992/ Per/X/1993 tentang Ketentuan dan Tatacara Pemberian izin Apotek, Dep. Kesehatan RI, Jakarta.

Depkes RI.2009. Peraturan Pemerintah Republik Indonesia Nomor 51 Tahun 2009 Tentang Pekerjaan Kefarmasian. Departemen Kesehatan RI: Jakarta.

Depkes RI.2009. Pharmaceutical care.Departemen Kesehatan RI, Jakarta.

Pudjaningsih.2007. Pengembangan Indikator Efisiensi Pengelolaan Obat di Farmasi Rumah Sakit. UGM Press. 